5th International Science Congress \& Exhibition APMAS2015, Lykia, Oludeniz, April 16-19, 2015

\title{
Characterisation of the Ancient City of Teos Western Necropolis Sherd Samples
}

\begin{abstract}
R.T. POlat ${ }^{a, *}$, A. TUnAli ${ }^{b}$
${ }^{a}$ Anadolu University, Literature Faculty, Department of Archaeology, 26470 Eskişehir, Turkey

${ }^{b}$ Ayşe Tunalı, Eczacibasi Building Products Co. VitrA Innovation Center, Bozuyuk, Bilecik, Turkey

Ancient city of Teos, one of the Ionian Religion Cities, is located in Sığacık district, Seferihisar Province in Izmir. The city was inhabited from Protogeometric period. The ancient city which has sheltered two harbors, due to its geographical position as a major trading center in the early emerges. Phokaia has been north of the city, Miletus has been south of the city, Samos and Khios Island have been in Ionian Cities. In this study, rescue excavations carried out by Izmir archaeological Museum in west and northwest of the city between 2013 and 2014. One of the necropolis is in the city as crow flies $1.1 \mathrm{~km}$ northwest, the other necropolis is located $1 \mathrm{~km}$ west of the city. This study will be dealt with the characterisation of clay and sherd samples which are obtained by necropolis. Samples from west and northwest of the necropolis of Teos City have been characterised by X-ray diffraction analyses and chemical analysis X-ray fluorescence methods.
\end{abstract}

DOI: 10.12693/APhysPolA.129.521

PACS/topics: 81.05.Je

\section{Introduction}

Teos ancient city, which is located in Seferihisar District Sığacık Neighborhood within the borders of İzmir province at the present time, was an important city in the center of Ionia region due to its geographical location. Due to its location, it was an important city in terms of military, politics and commerce with two sheltered harbors it had in ancient period. The perimeters of the city was fortified with a defense line as it was the case for many cities of the ancient period. The subject of this study is to create the characterization of the stones used in fortification walls of Teos city in Hellenistic Period.

Teos ancient city, which was located in the region referred to as Ionia region in Ancient Period, is located to $60 \mathrm{~km}$ south-west of İzmir Province in Seferihisar District Sığacık Neighborhood. The first research about Teos ancient city was conducted by British Society of Dilettanti in 1862. It was researched by the French in 1924 and 1925 and by Boysal and Öğün, academic members of Ankara University, between 1962 and 1966 [1-3]. Between 1980 and 1992, Mustafa Uz conducted limited drilling operations in the Archaic Temple and the sacred area of the Temple of Dionysus. Between 1993 and 1996, Tuna from Middle East Technical University conducted surface researches in and around the city. As from 2010, the archeological excavation and restoration studies in the city have been led by Kadıoğlu from Ankara University Faculty of Language, History and Geography, Department of Classical Archaeology [4, 5].

It was demonstrated by archeological remains and findings that Teos, which was an important city in terms of military, politics and commerce with two sheltered

*corresponding author; e-mail: rahsantp@anadolu.edu.tr

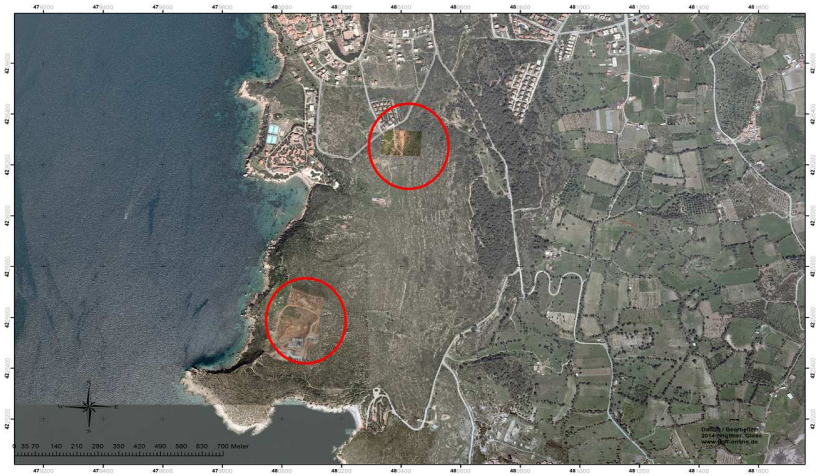

Fig. 1. The necropolis areas [6].

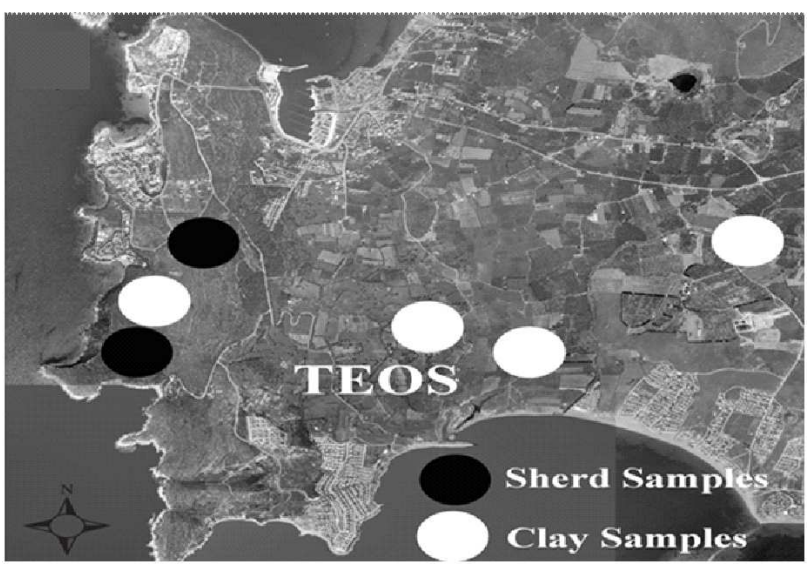

Fig. 2. Ceramic and clay samples acquired from necropolis areas [6].

harbors in ancient period, had been a settlement starting from Protogeometric Period [3]. In ancient Greece, necropolises are cemetery areas known as "the city of the dead". Limited number of cemeteries was found in both surface researches and salvage excavations around city of Teos and especially on the hills located to the west of the 
settlement. The existence of limited number of tombs dating different periods made it impossible to speculate in detail about the burial rituals seen in the necropolises of the city thus far. The necropolis areas detected in the salvage excavations conducted in 2013 and 2014 by İzmir Archaeological Museum in the west and northwest of the city (Fig. 1), the tomb types and burial rituals in these areas present important data for evaluating and speculating on the burial rituals of the Ionia region. Accordingly, the subject of this study is the characterization of ceramic and clay samples acquired from necropolis areas detected in the excavations conducted in 2013 and 2014 (Fig. 2), one of which is located $1100 \mathrm{~m}$ beeline north-west and the other $1 \mathrm{~km}$ west of the city. In this context, comparing the ceramic samples found in or around the tombs in said necropolis areas with the clay samples taken from the city and its vicinities and conducting the archaeometric analysis of the same have great importance for achieving healthier results. Designating the common and differentiating physical structures of ceramic and clay samples will provide information regarding the possible production technology in the ancient city.

\section{Experimental procedure}

The ceramic samples taken from north-west of Teos are coed as 1D, 2D, 3D, 4D; and those taken from the necrop- olis to the west are coded as $1,2,3,4,5$. Regarding the clay samples, the sample taken from the necropolis area is coded as 6 , the sample taken from near the fortification wall to the north-east of the city is coded as 7 , the sample taken from the area on which the city is located is coded as 8, and the sample taken from the acropolis is coded as 9. The ceramic and clay samples taken from the necropolis area to the west and north-west of Teos are analyzed in terms of archaeometrics by comparing to the earth/clay samples taken from the acropolis area of the city and its vicinities (stream bed). Chemical characterisation was carried out by means of wavelength dispersive X-ray fluorescence spectrometry (XRF), using a Philips model PW 2400 XRF instrument fitted with an $\mathrm{Rh}$ white fluorescent tube. The crystalline phases in the fired samples were determined by X-ray diffraction (XRD) analyses.

\section{Results and discussion}

Chemical analyses of the samples are shown in Table I. The XRF results of ceramic samples show that the samples taken from the north-west necropolis $(1 \mathrm{D}, 2 \mathrm{D}$, $3 \mathrm{D}, 4 \mathrm{D})$ and the samples taken from west necropolis $(1,2,3,4,5)$ are considerably similar in terms of chemical structure.

\section{TABLE I}

Chemical composition of samples.

\begin{tabular}{c|c|c|c|c|c|c|c|c|c|c}
\hline \hline & & \multicolumn{10}{|c}{ Components $[\mathrm{wt} \%]}$. \\
\cline { 3 - 10 } Area & Samples & $\mathrm{MgO}$ & $\mathrm{Al}_{2} \mathrm{O}_{3}$ & $\mathrm{SiO}_{2}$ & $\mathrm{~K}_{2} \mathrm{O}$ & $\mathrm{CaO}$ & $\mathrm{Fe}_{2} \mathrm{O}_{3}$ & $\mathrm{P}_{2} \mathrm{O}_{5}$ & $\mathrm{Na} 2 \mathrm{O}$ & L.O.I \\
\hline \multirow{3}{*}{ Teos 2013 } & $1 \mathrm{D}$ & 1.95 & 23.09 & 51.06 & 3.13 & 2.41 & 7.40 & 0.12 & 0.39 & 10.45 \\
northwest necropol & $2 \mathrm{D}$ & 2.22 & 23.35 & 51.16 & 2.27 & 4.39 & 7.82 & 0.12 & - & 8.67 \\
& $3 \mathrm{D}$ & 3.09 & 19.24 & 53.76 & 2.68 & 3.10 & 7.53 & 0.12 & - & 10.48 \\
& $4 \mathrm{D}$ & 1.82 & 20.33 & 53.33 & 3.05 & 3.20 & 6.70 & 0.14 & - & 11.43 \\
\hline \multirow{2}{*}{ Teos 2014 } & 1 & 2.18 & 21.67 & 51.54 & 3.45 & 1.90 & 6.97 & 0.12 & 0.52 & 11.65 \\
west & 2 & 2.29 & 21.18 & 52.9 & 2.8 & 6.40 & 6.98 & 0.11 & 0.61 & 7.45 \\
necropol & 3 & 2.27 & 19.96 & 55.25 & 3.09 & 1.36 & 6.36 & 0.09 & 0.93 & 10.69 \\
& 4 & 4.22 & 18.59 & 50.13 & 2.61 & 8.41 & 9.09 & 0.13 & 1.00 & 5.82 \\
Teos necropolis area & 6 & 2.40 & 21.34 & 51.32 & 2.69 & 6.39 & 7.57 & 0.12 & 0.79 & 7.38 \\
\hline near the fortification & & 0.87 & 7.73 & 32.18 & 1.16 & 29.27 & 3.07 & 0.03 & 0.17 & 25.52 \\
wall to the north-east & 7 & 3.85 & 14.64 & 49.9 & 3.07 & 3.37 & 6.09 & 0.15 & 3.71 & 15.22 \\
of the city & & & & & & & & & & \\
\hline city area & 8 & 1.57 & 19.98 & 44.9 & 3.24 & 6.75 & 9.62 & 0.12 & 0.32 & 13.5 \\
\hline acropolis area & 9 & 3.13 & 14.24 & 60.12 & 2.84 & 1.81 & 6.17 & 0.19 & 2.42 & 9.08
\end{tabular}

$\mathrm{SiO}_{2}(50-55 \%), \mathrm{Al}_{2} \mathrm{O}_{3}(19-23 \%)$ and $\mathrm{Fe}_{2} \mathrm{O}_{3}(6-8 \%)$ constitute the main element content of ceramic samples and the remaining part is formed by alkaline, alkaline soil and impurity grade $\mathrm{P}_{2} \mathrm{O}_{5}$. There is also a loss about $6-12 \%$.
When the mineralogical analysis patterns of ceramic samples taken from north-west necropolis in Fig. 3 and west necropolis in Fig. 4 are examined, it is seen that the samples include similar phases, particularly quartz, anorthite and illite/muscovite. In accordance with the 
results of the analysis, it can be stated that the samples were fired without exceeding $1000^{\circ} \mathrm{C}$, at around $900^{\circ} \mathrm{C}$. This is because the illite/muscovite seen in the structure of the samples degrade over $1000^{\circ} \mathrm{C}$.

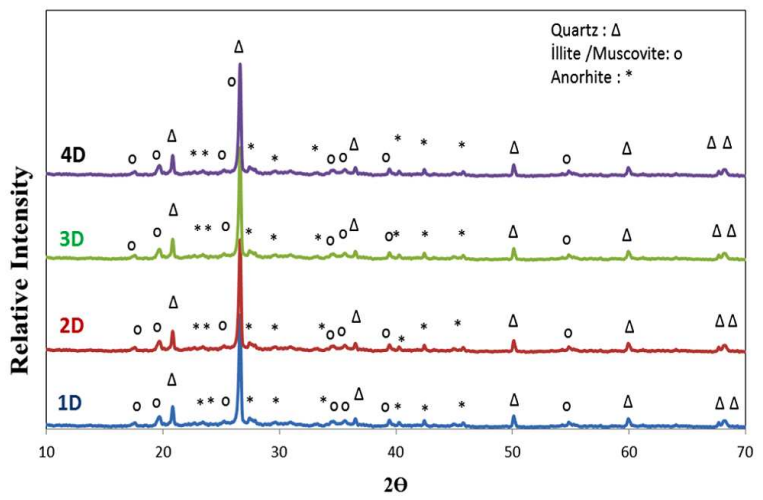

Fig. 3. XRD analyses of nothernwest necropolis ceramic samples coded as $1 \mathrm{D}, 2 \mathrm{D}, 3 \mathrm{D}$, and $4 \mathrm{D}$.

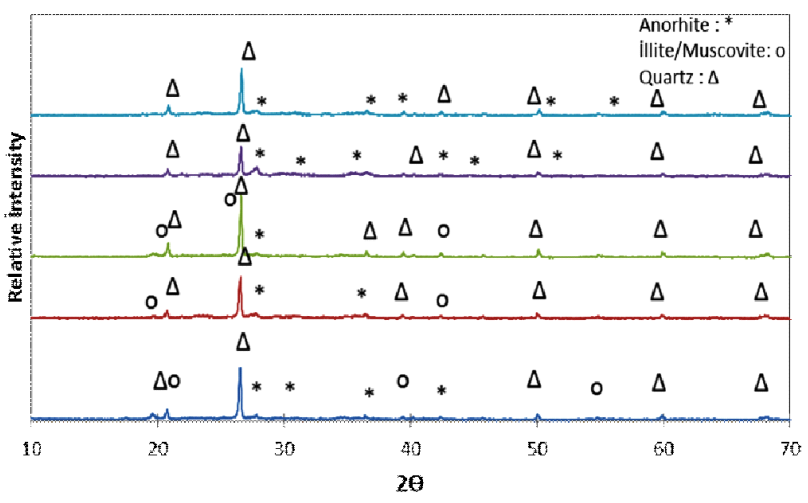

Fig. 4. XRD analyses of west necropolis ceramic samples coded as $1,2,3,4,5$.

When the chemical analysis result (Table I) of the clay samples $(6,7,8,9)$ is evaluated, it is seen that the clay samples are similar to ceramic samples in terms of main elements and the fire wasted. It is seen that the fire waste and $\mathrm{CaO}$ ratio are high only in the clay sample number 6 taken from the necropolis area. The result of the mineralogical analysis (Fig. 5) validates the result of the XRF and shows that a high amount of calcite is found in the sample number 6 . Moreover, it is seen that it comprises quartz, illite/muscovite, and a very small amount of kaolinite in its structure. Said clay is similar to the ceramic samples taken from the necropolis area. It can be said that while ceramic piece was being produced of said clay sample, kaolinite dehydrated with heat treatment and also the high amount of calcite in its structure degraded and a low amount of anorthite is formed in the final structure.

When the clay samples are evaluated in general, it is seen that they include high amounts of quartz and different ratios of albite, kaolinite, muscovite, montmorillonite, calcite phases which can be seen in raw clay as it is in

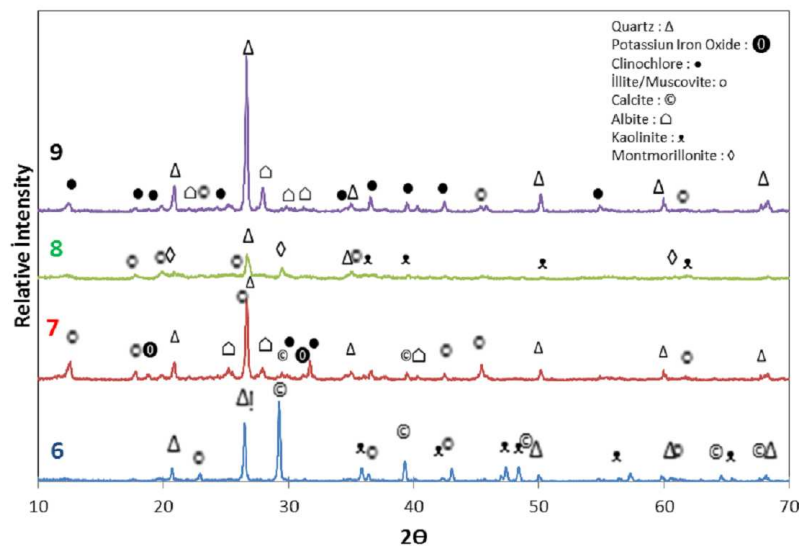

Fig. 5. XRD analyses of clay samples coded as $6,7,8$ and 9 .

the ceramic samples. Heterogeneous structure is seen in the clay sample number 7 . It can be said that as the clay sample is taken from an area close to water body, the clays carried with the water from different regions and the salt dissolved in the water cause the heterogeneous structure.

\section{Conclusions}

The XRF and XRD results of ceramic samples show that the samples taken from the north-west necropolis $(1 \mathrm{D}, 2 \mathrm{D}, 3 \mathrm{D}, 4 \mathrm{D})$ and the samples taken from west necropolis $(1,2,3,4,5)$ are considerably similar in terms of chemical and mineralogical structure. This makes it possible for us to consider that the ceramics taken from the necropolis area are made of clay taken from the same clay deposit.

Also the contents of the clay sample taken from the necropolis area were consistent with the ceramic samples. It can be deduced that the ceramic pieces taken from the necropolis area are made of the clay in the region.

\section{References}

[1] Y. Boysal, Türk Arkeoloji Dergisi XII-II, 5 (1963) (in Turkish).

[2] Y. Boysal, B. Öğün, Türk Arkeoloji Dergisi XII-I, 12 (1963) (in Turkish).

[3] B. Öğün, Türk Arkeoloji Dergisi XIII-I, 115 (1964) (in Turkish).

[4] M. Kadıŏlu, M. Adak, C. Özbil, S.H. Öztaner, R.T. Polat, Y. Polat, Kazı Sonuçları Toplantısı 33, 429 (2011) (in Turkish).

[5] M. Kadıŏlu, M. Adak, C. Özbil, S.H. Öztaner, R.T. Polat, Y. Polat, Kazı Sonuçları Toplantısı 34, 211 (2012) (in Turkish).

[6] Google Earth application. 